\title{
PREVALENCE OF VIT A DEFICIENCY IN RURAL POPULATION OF UTTAR PRADESH
}

\author{
Rakesh Sharma1, Gursimran Kaur², B. K. Shrivastava ${ }^{3}$
}

${ }^{1}$ Associate Professor, Department of Ophthalmology, Mayo Institute of Medical Sciences, Barabanki. ${ }^{2}$ Assistant Professor, Department of Ophthalmology, Mayo Institute of Medical Sciences, Barabanki. ${ }_{3}^{3}$ Medical Superintendent, Department of Ophthalmology, Mayo Institute of Medical Sciences, Barabanki.

\begin{tabular}{l}
\hline ABSTRACT \\
BACKGROUND \\
transparency of cornea, which is very difficult to manage in India.
\end{tabular}

The aim of this study was to find out the prevalence of Vitamin A deficiency in peripheral part of Lucknow and Barabanki, (Uttar Pradesh).

\section{MATERIALS AND METHODS}

This study was done in Mayo Institute of Medical Sciences (Uttar Pradesh), in which children aged 0-12 years were undertaken. Study population was selected by examining students at schools by Bal Suraksha Guarantee Yojna team and the OPD population of paediatrics and obstetrics and gynaecology, 1598 children and students participated in the study. Students were from $1^{\text {st }}$ to $7^{\text {th }}$ class, age was 0-12 years.

\section{RESULTS}

Prevalence of xerophthalmia was $4.29 \%$ in all the age group of 0-12 years. Prevalence of Bitot's spot was $1.8 \%$ in children under six years of age and $4.93 \%$ in children above six years. The prevalence of xerophthalmia was significantly more in children over 6 years of age. Prevalence of anaemia was $18.4 \%$ in the study. High prevalence of xerophthalmia was observed in children suffering from anaemia, which conveys more of disease prevalence in weak and malnourished children.

\section{CONCLUSION}

With the effort of the Government Agencies and the NGOs, the manifestation of xerophthalmia and prevalence of Bitot's spot in children under six years of age in the present study shows a declining manifestations of even the first sign of vit A deficiency, although it is still a public health problem. The higher prevalence in children above six years of age shows that apart from strengthe ning of vitamin A prophylaxis programs, health education is required so as to maintain and strengthen our goal.

\section{KEYWORDS}

Vitamin A, Bitot's Spot, Prophylaxis, Xerophthalmia.

HOW TO CITE THIS ARTICLE: Sharma R, Kaur G, Shrivastava BK. Prevalence of vit A deficiency in rural population of Uttar Pradesh. J. Evolution Med. Dent. Sci. 2016;5(90):6667-6669, DOI: 10.14260/jemds/2016/1508

\section{BACKGROUND}

Vitamin A is essential for maintenance and recycling of visual pigment (Rhodopsin) and maintenance of epithelial and cellular integrity. Vitamin A deficiency can occur at any age, which is a potentially disabling condition for children under six years of age.[1,2] Bitot's spots reflect the past history of Vitamin A Deficiency (Sommer et al 1980). Studies have shown that Vitamin A deficiency causes night blindness, which has a great impact on general development and growth of children. ${ }^{[3]}$ Vit A deficiency is regarded as a public health problem, if the prevalence of Bitot's spots amongst children less than six years is $0.5 \%$ or more (WHO 1996). Recent data shows that only $30 \%$ of children had received a dose of vitamin A through all the Government schemes (Indian Institute of

Financial or Other, Competing Interest: None.

Submission 01-09-2016, Peer Review 14-09-2016,

Acceptance 16-09-2016, Published 09-11-2016.

Corresponding Author:

Dr. Rakesh Sharma

\#592/115 D, Rajiv Nagar,

Telibagh, Lucknow-226025,

Uttar Pradesh.

E-mail: rakeshsharma1909@gmail.com

DOI: $10.14260 /$ jemds/2016/1508

\section{(c) $(i) \risingdotseq$}

Population Sciences, Mumbai 2000). Very few studied on Vitamin A Deficiency have included school children apart from pre-school children. Therefore, the present study was undertaken amongst children $0-12$ years, so as to estimate the prevalence of vit A deficiency in children of 0-12 years in rural area of Barabanki and Lucknow (Uttar Pradesh) ${ }^{[4]}$ and with the emphasis laid on demographic variables.

\section{MATERIALS AND METHODS}

This study was done in the rural areas of Lucknow and Barabanki (Uttar Pradesh). A total of 1598 children of 0-12 years were enrolled for the study. Out of these 86 could not be included because of loss to follow-up, hence 1512 children formed the study subjects. A survey was carried out by the BSGY team to various schools (26 in number) and the OPD patients in paediatrics and $O$ and $G$ Department and information was obtained as per the content of the proforma. The information collected included the name, age, sex, address and the class of the student and the occupation of father, income of the parents and family size. The socioeconomic status of the study subjects was estimated as per the modified Kuppuswamy socioeconomic scale (Mahajan and Gupta, 1995). This scale is based on three variables of the family: education, occupation of the head of the family and the total monthly income of family. Scores have been assigned to each 
of the different categories under these three variables and a combined score is used for grading the socioeconomic status.

Haemoglobin estimation of all children was carried out and the cut-off point of $11 \mathrm{~g} / \mathrm{dL}$ for children under six years and $12 \mathrm{~g} / \mathrm{dL}$ for children above six years of age were considered for the diagnosis of anaemia (Park, 2011). Children suffering from xerophthalmia were given 200,000 IU of Vitamin A orally for two days. The statistical analysis was carried out by the chi-square test and the odds ratio with its 95\% confidence interval.

\section{RESULTS}

\section{Table 1. Prevalence of Xerophthalmia According to Age}

- The overall prevalence of xerophthalmia was found to be $4.29 \%$. Only the milder manifestations of xerophthalmia, i.e. night blindness and Bitot's spots were observed.

- No case of corneal Stage X2, X3A, X3B, XS was seen, though the prevalence of xerophthalmia was $4.29 \%$,

- $\quad$ Overall prevalence of signs and symptoms was $4.03 \%$.

- Prevalence of Bitot's spot was $1.83 \%$ in children under six years of age and $4.93 \%$ in children above six.

- The increase in the prevalence of xerophthalmia with the increase in age group was found to be statistically significant.

\begin{tabular}{|c|c|c|c|c|c|}
\hline $\begin{array}{c}\text { Age } \\
\text { of } \\
\text { Group }\end{array}$ & $\begin{array}{c}\text { Number } \\
\text { of } \\
\text { Children }\end{array}$ & $\begin{array}{c}\text { With } \\
\text { Night } \\
\text { Blindness } \\
(\mathrm{XN})\end{array}$ & $\begin{array}{c}\text { With } \\
\text { Bitot's } \\
\text { Spot (X1B) }\end{array}$ & $\begin{array}{c}\text { Night } \\
\text { Blindness+ } \\
\text { Bitot's } \\
\text { Spots }\end{array}$ & Total \\
\hline $\begin{array}{c}0-3 \\
\text { years }\end{array}$ & 360 & $0(0 \%)$ & $2(.55 \%)$ & 0 & $2(.55 \%)$ \\
\hline $\begin{array}{c}4-6 \\
\text { years }\end{array}$ & 389 & $5(1.28 \%)$ & $5(1.28 \%) 1$ & $2(.51 \%)$ & $12(3.07 \%)$ \\
\hline $\begin{array}{c}7-9 \\
\text { years }\end{array}$ & 386 & $7(1.81 \%)$ & $6(1.55 \%)$ & $3(1.77 \%)$ & $16(4.13 \%)$ \\
\hline $\begin{array}{c}10-12 \\
\text { years }\end{array}$ & 377 & $14(3.6 \%)$ & $13(3.38 \%)$ & $8(2.08 \%)$ & $35(9.06 \%)$ \\
\hline \multicolumn{7}{|c|}{ Total } & 1512 & $\mathbf{2 6 ( 1 . 7 1 \% )}$ & $\mathbf{2 6 ( 1 . 7 1 \% )}$ & $\mathbf{1 3 ( . 8 5 \% )}$ & $\mathbf{6 5}(4.29 \%)$ \\
\hline \multicolumn{7}{|c|}{ Table 1: Comparative Analysis of Xerophthalmia } \\
\hline
\end{tabular}

\begin{tabular}{|c|c|c|c|}
\hline $\begin{array}{c}\text { Demographic } \\
\text { Factor }\end{array}$ & $\begin{array}{c}\text { Study } \\
\text { Subject }\end{array}$ & Xerophthalmia & P Value \\
\hline $\begin{array}{c}\text { Males } \\
\text { Females }\end{array}$ & $\begin{array}{l}802 \\
710 \\
\end{array}$ & $\begin{array}{l}45(5.6 \%) \\
20(2.5 \%)\end{array}$ & 0.89 \\
\hline $\begin{array}{c}\text { Socio-Economic Status } \\
\text { Middle Class } \\
\text { Lower Class } \\
\end{array}$ & $\begin{array}{l}588 \\
924 \\
\end{array}$ & $\begin{array}{l}20(3.4 \%) \\
45(4.8 \%) \\
\end{array}$ & 1.76 \\
\hline $\begin{array}{c}\text { Family Size } \\
\text { Less than } 5 \text { Member } \\
\text { More than } 5 \text { Member }\end{array}$ & $\begin{array}{l}894 \\
618\end{array}$ & $\begin{array}{l}33(3.66 \%) \\
32(5.15 \%)\end{array}$ & 0.59 \\
\hline \multicolumn{4}{|c|}{ Table 2} \\
\hline
\end{tabular}

\begin{tabular}{|c|c|c|c|}
\hline Anaemia & $\begin{array}{l}\text { With Xero- } \\
\text { phthalmia }\end{array}$ & $\begin{array}{c}\text { Without } \\
\text { Xero- } \\
\text { phthalmia }\end{array}$ & Total \\
\hline $\begin{array}{c}\text { With } \\
\text { Anaemia }\end{array}$ & $36(18.4 \%)$ & $159(81.6 \%)$ & $195(12.9 \%)$ \\
\hline $\begin{array}{l}\text { Without } \\
\text { Anaemia }\end{array}$ & $29(2.20 \%)$ & $1288(97.8 \%)$ & 1317(87.1\%) \\
\hline Total & 65(4.29\%) & 1447(95.71\%) & $1512(100 \%)$ \\
\hline
\end{tabular}

Figures in parenthesis are percentages; $\mathrm{X} 2=105.23$; $\mathrm{P}=$ less than 0.001 (Highly significant) $\mathrm{OR}=10.056$; $95 \%$ Confidence limits $=5.26-16.848$.
Table 2 describes the prevalence of xerophthalmia according to sociodemographic factors. A higher prevalence of xerophthalmia was observed in boys, lower socioeconomic status and children with family size of five and above; however, the difference was not significant. The overall prevalence of anaemia was in the study population $12.9 \%$. A high prevalence of xerophthalmia was observed in children suffering from anaemia (Table 3). Estimates of odds ratios and their 95\% confidence intervals confirmed significant association between xerophthalmia and anaemia.

\section{DISCUSSION}

Vit. A deficiency is a major cause of preventable blindness and disabling public health problem in children of India. A very few studies have been done here to access the load of vit A deficiency in children of all age groups. The current study observed $4.29 \%$ prevalence of xerophthalmia in children up to 12 years. The earlier-conducted studies have reported a prevalence of xerophthalmia in the range of $1.1 \%$ to $22.3 \%$ in different population groups and in different parts of the country[5,6] and different socio-economical groups. ${ }^{[7,8]}$

Now-a-days, there are reports of decrease in the prevalence of Vitamin A deficiency, which is due to the efforts of Government Health Agencies and various NGO organisations who are running prophylaxis immunisation programs and oral vit. A dose has been made compulsory and has been included in national immunisation program. ${ }^{[9,10]}$ So there are milder manifestations of xerophthalmia, which shows that the prevalence of vit. A deficiency is on the decline. This study shows a significantly higher prevalence of vitamin A deficiency in the older age groups $>6$ years. Similar findings (Sharma SK, et al 1985; Fakhir S, et al 1993) have also been reported by other investigators. The observed association with anaemia, low socioeconomic status and low intake of nutrients and is generally associated with various infections which further precipitates or aggravate vitamin A deficiency.

\section{CONCLUSION}

Our study tells about the prevalence of xerophthalmia prevalence in children between $0-12$ year's age, which is $1.8 \%$ but is still high enough and should be under $0.5 \%$ as directed by the WHO guidelines.

\section{A Multidisciplinary Approach is required to Tackle with this Problem}

- Education of parents.

- $\quad$ Easy approach to health facilities.

- Community participation.

- Screening of children in schools.

- Health education.

- $\quad$ Limited family size.

- Dietary diversification.

Such an approach will improve all the deficiency diseases and make the child fit and aid in the development of country.

\section{REFERENCES}

1. World Health Organization. Indicators for assessing vitamin a deficiency and their application in monitoring and evaluation intervention program. Geneva: WHO 1996:5-14. 
2. WHO technical report series no. 590, vitamin A deficiency and xerophthalmia report of a joint WHO/USAID meeting. 1976:17-8.

3. Rahmathullah L, Underwood BA, Thulasiraj RD, et al. Reduced mortality among children in southern India receiving a small weekly dose of vitamin A. New Eng J Med 1990;323(14):929-35.

4. Sampathkumar V, Abel R. Xerophthalmia in rural south Indian children. Indian Pediatr 1993;30(2):246-8.

5. Sharma SK, Mathur GP, Mathur S, et al. An epidemiological study of hypovitaminosis A in preschool children of urban slums in Gorakhpur. Indian J Prev Soc Med 1985;16(4):131-6.

6. Chainani N, Sharma P, Meena N, et al. Pattern of vitamin deficiencies among the malnourished preschool children in ICDS blocks of Jaipur city. Indian Journal of Maternal and Child Health 1994;5(4):109-11.
7. Katiyar GP, Jaiswal P, Reddy DCS, et al. Biosocial determinants of xerophthalmia in under-five children. Indian J Prev Soc Med 1986;17(2):69-78.

8. Pal R, Sagar V. Antecedent risk factors of xerophthalmia among Indian rural preschool children. Eye Contact Lens 2008;34(2):106-8.

9. Mahajan BK, Gupta MC. Textbook of preventive and social medicine. $2^{\text {nd }}$ edn. New Delhi: Jaypee Brothers Medical Publishers (P) Ltd 1995:134-5.

10. Park K. Parks textbook of preventive and social medicine. 21st edn. Jabalpur: Banarsidas Bhanot 2011:561-617. 